International Journal of Social Sciences and Humanities
Available online at www.sciencescholar.us
Vol. 6 No. 1, April 2022, pages: 58-65
e-ISSN: 2550-7001, p-ISSN: 2550-701X
https://doi.org/10.53730/ijssh.v6n1.3528

\title{
Correlation of Fiber Intakes with Incidence of Constipation in the Elderly
}

\author{
Savitri Gemini a ${ }^{\text {, Lestari Lorna Lolo }}{ }^{\text {b }}$, Sumiati ${ }^{c}$, Awaliyah Ulfah Ayudytha Ezdha ${ }^{\text {d }}$, Neny Yuli Susanti ${ }^{\text {e }}$
}

Manuscript submitted: 18 November 2021, Manuscript revised: 09 December 2021, Accepted for publication: 27 January 2022

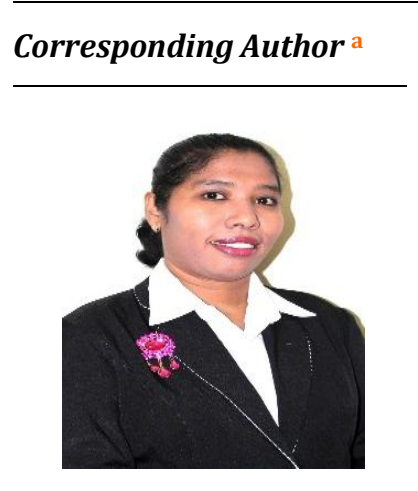

Keywords

constipation;

elderly;

fiber intakes;

implications;

nutrition;

\begin{abstract}
Constipation becomes one of the diseases that are often suffered by the elderly, many factors that affect constipation one of which is fiber intake. The goal of the study was to find out the relationship of fiber intake with the incidence of constipation in the elderly (elderly). The research is conducted with a crosssectional approach. The number of samples in the study as many as 65 elderly, sampling using purposive sampling techniques. The majority of research results obtained fiber intake of fewer than 50 people (76.9\%), constipation as many as 34 people $(52.3 \%)$, adequate fiber intake as many as 15 people $(23.1 \%)$, and not constipation as many as 31 people (47.7\%). The chi-square test result was $p$-value $0.010(\alpha=<0.05)$, suggesting there was a meaningful relationship between fiber intake and constipation events. The conclusion of a study of less fiber intake can result in constipation in the elderly. The implications of the research are shown so that the elderly can maintain fiber intake patterns and avoid the occurrence of constipation.
\end{abstract}

International Journal of Social Sciences and Humanities (C) 2022.

This is an open access article under the CC BY-NC-ND license (https://creativecommons.org/licenses/by-nc-nd/4.0/).

\section{Contents}

Abstract.

1 Introduction

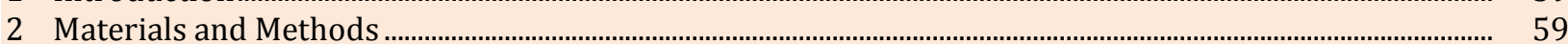

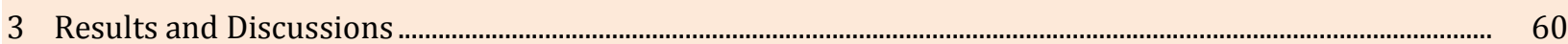

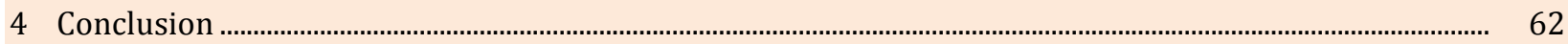

Acknowledgments...................................................................................................................................................... 62

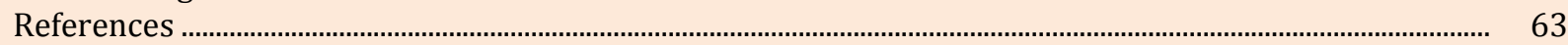

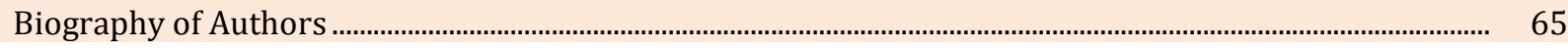

\footnotetext{
a Mitra Bunda Health Institute, Batam, Indonesia

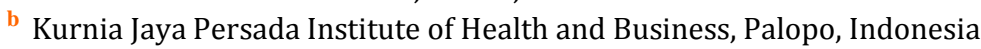

c Kurnia Jaya Persada Institute of Health and Business, Palopo, Indonesia

${ }^{d}$ Pekanbaru Medical Center College of Health Sciences, Pekanbaru, Indonesia

e Ibrahimy University, Situbondo, Indonesia
} 


\section{Introduction}

An elderly person is someone who has reached the age of 60 years and above. Aging is not a disease, but is a process that gradually results in cumulative changes, is the process of decreasing endurance in the face of stimulation from inside and outside the body. With age, the elderly experience various changes in the body, namely the decrease in the function of various organs and tissues of the body (Purnomo et al., 2019). These changes include sensing organs that lower appetite, weakening of the digestive system becomes more sensitive to food, and constipation (Aspiani, 2014). Constipation is defined as changes in the frequency of defecation, volume, and consistency of feces. Constipation is not a disease, but rather a symptom of decreased frequency of defecation ( $>3$ days once or $<2$ times a week) followed by the production of long stools with a hard and dry consistency (Damon et al., 2004; Locke III et al., 2000). Constipation occurs due to decreased colon motility thus extending the transit time of feces in the colon and resulting in the water content continuing to be absorbed from the fecal mass so that the stool becomes dry, hard, and difficult to remove in the defecation process (Gutzwiller, 2011). According to (Dennison et al., 2005), elderly people in the United States who experience complaints of constipation as many as 2.5 million people, the prevalence of constipation in the elderly $>65$ years as much as $30 \%-40 \%$. Studies of the population in Turkey show constipation rates from $22 \%$ to $40 \%$. Constipation occurs in Indonesia by $3.8 \%$ for the elderly aged $60-69$ years, and the elderly over 70 years of age by $6.3 \%$ (Kemenkes, R.I, 2017). The incidence of constipation in Indonesian women is higher than men 2-3 times. The prevalence of constipation in the elderly $>60$ years of age is $33.5 \%$ and $80 \%$ of the elderly are hospitalized (Mansouri et al., 2018). According to Riwidikdo (2009), elderly people who experience constipation are as many as 20 people with a prevalence of low fiber intake as much as $100 \%$, fluid intake less as much as $38.5 \%$, and less physical activity as much as $10 \%$. The main causes of constipation are lack of fibrous food consumption, lack of fluid intake, physical activity, prolonged baring, heavy laxative use that leads to loss of normal reflex defecation (Potter \& Perry, 2005). Adequate fiber intake can facilitate the defecation process (Mustika \& Harini, 2017). This fiber will bind to fat so that the fat will not be absorbed by the body, but will be removed from the body with feces (Reicks et al., 2014; Dukas et al., 2003; Marlett \& Cheung, 1997). Less fiber intake can cause constipation (McCrea et al., 2009). The more adequate fiber intake, the more normal the frequency of defecation is above 3 times a week and vice versa the less fulfilled fiber intake than the frequency of defecation will be reduced, which is below 3 times/week (Sugiyanto et al., 2017). Lack of fiber intake is one of the causes of difficulty defecating, because the lack of fiber intake results in feces that form become hard, dry, and difficult to remove, and if ignored can cause severe obstipation. Severe obstipation can result in colon cancer that is fatal for the sufferer (Mulyani, 2019), Various changes experienced by the elderly, ranging from decreased body function, physical ability, patterns of dietary consumption of fiber sources, and fulfillment of fluid intake in the body cause the risk of elderly experience constipation to be greater than at a young age (Hajjar et al., 2007; Kerrigan et al., 1998).

\section{Materials and Methods}

This research is included in the type of analytical research WI cross-sectional design. The sample in this study was elderly people aged $\geq 60$ years in the working area of the health center said Langkawi with a large sample of 65 people. Sampling technique using non-probability sampling with purposive sampling technique. The instrument used in this study was a questionnaire. Questionnaires used for fiber intake are SQ-FFQ (SemiQuantitative Food Frequency Questioner) and Nutri survey software 2007. This SQ-FFQ questionnaire consists of 5 indicators of fiber intake, namely whole grains, vegetables, fruits, nuts, and drinks. Questionnaire assessments use a rating scale by answering using respondents' perceptions. Nutrisurvey software consists of a menu of foods, amounts, various sources of nutrition (carbohydrates, proteins, fats, fiber, vitamins, sodium, potassium, calcium, magnesium, zinc, etc.), age, and portions (Wild et al., 2010; Gramlich et al., 2004). The constipation questionnaire used is a CSS questionnaire (Constipation Scoring System) consisting of 8 indicators of constipation, namely the frequency of bowel movements, difficulty emptying. Or painful, complete

Gemini, S., Lolo, L. L., Sumiati, S., Ezdha, A. U. A., \& Susanti, N. Y. (2022). Correlation of fiber intakes with incidence of constipation in the elderly. International Journal of Social Sciences and Humanities, 6(1), 58-65. https://doi.org/10.53730/ijssh.v6n1.3528 
emptying, abdominal pain, length in the toilet to defecate, the type of help used, emptying efforts failed for 24 hours, and the length of constipation (Mustika \& Sudiantara, 2019). Assessment using a Likert scale in the form of a statement with a value of 4 for answers has been always a value of 3 for frequent answers, a value of 2 for answers sometimes, the value of 1 for the answer is rare, the value of 0 for the answer never. The data analysis used in this study is a univariate analysis of this study consisting of free variables, namely fiber intake and bound variables that are constipation events, carried out by calculations (Suwananta et al., 2020). Presentation. Bivariate analysis is used using a chi-square statistical test.

\section{Results and Discussions}

The results of this study were conducted in the working area of Puskesmas Sei lanky Batam city in 2020, starting with spreading questionnaires about fiber intake and constipation events to 65 elderly people. The data of questionnaire deployment results consists of general data and specialized data.

Table 1

Elderly demographic data in the working area of Puskesmas Sei Langkai in Batam city in 2020

\begin{tabular}{|c|c|c|}
\hline Variable & Sum & Percentage (\%) \\
\hline \multicolumn{3}{|l|}{ Age } \\
\hline $60-64$ & 41 & 63,1 \\
\hline $65-69$ & 14 & 21,5 \\
\hline $70-74$ & 5 & 7,7 \\
\hline $75-80$ & 5 & 7,7 \\
\hline \multicolumn{3}{|l|}{ Gender } \\
\hline Man & 24 & 36,9 \\
\hline Woman & 41 & 63,1 \\
\hline \multicolumn{3}{|l|}{ Work } \\
\hline Work & 8 & 12,3 \\
\hline Not Working & 57 & 87,7 \\
\hline \multicolumn{3}{|l|}{ Education } \\
\hline Not school & 10 & 15,4 \\
\hline Primary Education & 41 & 63,1 \\
\hline Secondary Education & 14 & 21,5 \\
\hline Higher Education & 0 & 0 \\
\hline \multicolumn{3}{|l|}{ Elderly Height } \\
\hline $148-150 \mathrm{~cm}$ & 11 & 16,9 \\
\hline $151-153 \mathrm{~cm}$ & 7 & 10,8 \\
\hline $154-156 \mathrm{~cm}$ & 14 & 21,5 \\
\hline $157-159 \mathrm{~cm}$ & 10 & 15,4 \\
\hline $160-162 \mathrm{~cm}$ & 14 & 21,5 \\
\hline $163-165 \mathrm{~cm}$ & 5 & 7,7 \\
\hline $166-168 \mathrm{~cm}$ & 1 & 1,5 \\
\hline $169-171 \mathrm{~cm}$ & 3 & 4,6 \\
\hline \multicolumn{3}{|l|}{ Elderly Weight } \\
\hline $48-52 \mathrm{~kg}$ & 12 & 18,5 \\
\hline $53-57 \mathrm{~kg}$ & 14 & 21,5 \\
\hline $58-62 \mathrm{~kg}$ & 24 & 36,9 \\
\hline $63-67 \mathrm{~kg}$ & 5 & 7,7 \\
\hline $68-72 \mathrm{~kg}$ & 7 & 10,8 \\
\hline $73-77 \mathrm{~kg}$ & 2 & 3,1 \\
\hline $78-82 \mathrm{~kg}$ & 1 & 1,5 \\
\hline
\end{tabular}


Table 2

Distribution of elderly stick character frequency based on fiber intake

\begin{tabular}{lcc}
\hline \multirow{2}{*}{ Fiber Intake } & \multicolumn{2}{c}{ Sum } \\
\cline { 2 - 3 } & Frequency & $(\%)$ \\
\hline Enough & 15 & 23,1 \\
Less & 50 & 76,9 \\
Total & 65 & 100 \\
\hline
\end{tabular}

From Table 2 above known most of the fiber intake of the elderly less amounted to 50 elderly (76.9\%).

Table 3

Distribution of elderly stick character frequency based on constipation events

\begin{tabular}{lcc}
\hline \multirow{2}{*}{ Constipation Event } & \multicolumn{2}{c}{ Sum } \\
\cline { 2 - 3 } & Frequency & $(\%)$ \\
\hline No Constipation & 31 & 47,7 \\
Constipation & 34 & 52,3 \\
Total & 65 & 100 \\
\hline
\end{tabular}

Table 3 data shows beware most of the elderly experiencing constipation amounted to 34 elderly (52.3\%).

Table 4

Results of analysts' relationship of fiber intake with constipation events in the elderly

\begin{tabular}{|c|c|c|c|c|c|c|c|}
\hline \multirow{3}{*}{$\begin{array}{l}\text { Fiber Intake } \\
\text { Variables }\end{array}$} & \multicolumn{4}{|c|}{ Constipation Event } & \multicolumn{2}{|c|}{ Total } & \multirow{3}{*}{ p-area } \\
\hline & \multicolumn{2}{|c|}{ No constipation } & \multicolumn{2}{|c|}{ Constipation } & \multirow[t]{2}{*}{$\mathrm{n}$} & \multirow[t]{2}{*}{$(\%)$} & \\
\hline & $\sum$ & $(\%)$ & $\sum$ & $(\%)$ & & & \\
\hline Enough & 12 & 80 & 3 & 20 & 15 & 100 & \\
\hline Less & 19 & 38 & 31 & 62 & 50 & 100 & 0,010 \\
\hline Total & 31 & 47,7 & 34 & 52,3 & 65 & 100 & \\
\hline
\end{tabular}

Based on table 4 above, the chi-square test result with a p-value of $0.010(\alpha=\leq 0.05)$ was obtained so that Ho was rejected and $\mathrm{H} \alpha$ accepted. So the conclusion is that there is a relationship between fiber intake with the occurrence of constipation in the elderly in the working area of Puskesmas Sei Langkai Batam City in 2020.

Fiber is a non-pathic polysaccharide in the form of complex carbohydrates formed from the combination of several simple sugar groups. Fiber is a non-nutritional nutrient that cannot be digested by human digestive enzymes so the fiber does not produce energy and nutrients (Winarto, 2004). The function of fiber in the digestive system is to increase the volume of feces, and facilitate defecation or defecation, so that fiber can prevent constipation (Sugiyanto et al., 2017). A fiber consisting of soluble and insoluble fiber, dietary fiber has been shown to overcome the problem of constipation in the elderly, a good source of fiber found in grains, vegetables, fruits, and nuts. Insoluble dietary fiber consists of cellulose, hemicelluloses, and lignin. Cellulose and hemicellulose are found in wheat, sweet potatoes, kale, chickpeas, Tampa, guava, lignin widely found in the wood section grainy plants, apples, cabbage. While soluble dietary fiber consists of gum, pectin, and mucilage. Pectin is found on the skin of vegetable plants, such as apples, oranges, and sesame. Gum is widely found in nuts such as soybeans, chickpeas, and mucilage. On the outside of the grain cell (Senate, 2018). People who consume low fiber will slow down the transit time of food in the intestines that can cause because fiber also serves to facilitate the volume of feces so that it will facilitate the disposal process, if the respondent's fiber consumption is low it will cause constipation (Mardalena, 2018). In this study, the fulfillment of fiber needs is very affordable and easy to obtain. Supposed fiber intake is likely to be enough, but

Gemini, S., Lolo, L. L., Sumiati, S., Ezdha, A. U. A., \& Susanti, N. Y. (2022). Correlation of fiber intakes with incidence of constipation in the elderly. International Journal of Social Sciences and Humanities, 6(1), 58-65. https://doi.org/10.53730/ijssh.v6n1.3528 
in the results of research that fiber intake tends to be less, then there is a problem with the consumption of foods consumed foods that make the fiber. Unfulfilled. Constipation is a disorder of the digestive tract caused by dry and hard stool through the large intestine and caused by various actors such as fiber, fluids, and Poor lifestyle, such as physical activity, stress, and bowel movements (Oktaviana \& Setiarini, 2013) Elderly is someone who has reached the age of 60 years and above, elderly is the aging process, not a disease. This process is characterized by changes from inside and outside the body, one of which is a functional problem in the digestive system that causes constipation in the elderly (Stanhope \& Lancaster, 2019). Constipation In the elderly occurs due to weak peristaltic, tooth loss, decreased intestinal motility, and loss of abdominal muscle elasticity (Aspiani, 2014). According to Potter \& Perry (2005), constipation is caused by irregular defecation habits, consumption of a low-fiber diet, long boring, age, and drug use. Sedating. In this study, the elderly pay less attention to bowel habits, the elderly delay defecation due to emptying that is difficult/painful and not the completion of defecation so that the elderly tend to hold or delay it. The way to avoid constipation is to get used to regular bowel movements and consume foods that contain fiber. Elderly people who experience constipation tend to be due to less fiber intake. This happens because the elderly do not spend their food on the grounds of not appetite, another factor that worsens fiber intake in the elderly, namely the completeness of teeth that are already a lot of dates result in the inability to chew foods that contain fiber sources (Massacre \& Audina, 2018). Factors associated with constipation, according to Turan et al. (2011), i.e. Irregular defecation habits, lack of Fiber intake, prolonged baring, taking drugs such as sedatives, Parkinson's drugs, increased psychological stress, and weakening of muscle tone.

\section{Conclusion}

The results of the above research, researchers assume that the relationship fiber intake with the incidence of constipation most respondents consumes less fiber. Fiber serves to increase the volume of feces and facilitate bowel movements, so that fiber can prevent constipation. This suggests that fiber has a significant role to play in the increased frequency of constipation. So it can be concluded based on the results of research that there is a relationship between the two variables, namely the less fiber intake, the higher the incidence of constipation. And adequate fiber intake then the occurrence of constipation can be overcome.

Acknowledgments

We are grateful to two anonymous reviewers for their valuable comments on the earlier version of this paper. 


\section{References}

Aspiani, R. Y. (2014). Gerontic Nursing Teaching Book: Application of NANDA, NIC and NOC volume 1. Jakarta: Trans Info Media.

Damon, H., Dumas, P., \& Mion, F. (2004). Impact of anal incontinence and chronic constipation on quality of life. Gastroentérologie clinique et biologique,28(1), 16-20. https://doi.org/10.1016/S03998320(04)94835-X

Dennison, C., Prasad, M., Lloyd, A., Bhattacharyya, S. K., Dhawan, R., \& Coyne, K. (2005). The health-related quality of life and economic burden of constipation. Pharmacoeconomics, 23(5), 461-476.

Dukas, L., Willett, W. C., \& Giovannucci, E. L. (2003). Association between physical activity, fiber intake, and other lifestyle variables and constipation in a study of women. The American journal of gastroenterology, 98(8), 1790-1796. https://doi.org/10.1016/S0002-9270(03)00442-8

Gramlich, L., Kichian, K., Pinilla, J., Rodych, N. J., Dhaliwal, R., \& Heyland, D. K. (2004). Does enteral nutrition compared to parenteral nutrition result in better outcomes in critically ill adult patients? A systematic review of the literature. Nutrition, 20(10), 843-848. https://doi.org/10.1016/j.nut.2004.06.003

Gutzwiller, J. P., Aschwanden, J., Iff, S., Leuenberger, M., Perrig, M., \& Stanga, Z. (2011). Glucocorticoid treatment, immobility, and constipation are associated with nutritional risk. European journal of nutrition, 50(8), 665-671.

Hajjar, E. R., Cafiero, A. C., \& Hanlon, J. T. (2007). Polypharmacy in elderly patients. The American journal of geriatric pharmacotherapy, 5(4), 345-351. https://doi.org/10.1016/j.amjopharm.2007.12.002

Kemenkes, R.I. (2017). Health profile of the Republic of Indonesia in 2017. Ministry of Health. Jakarta.

Kerrigan, D. C., Todd, M. K., Della Croce, U., Lipsitz, L. A., \& Collins, J. J. (1998). Biomechanical gait alterations independent of speed in the healthy elderly: evidence for specific limiting impairments. Archives of physical medicine and rehabilitation, 79(3), 317-322. https://doi.org/10.1016/S0003-9993(98)90013-2

Locke III, G. R., Pemberton, J. H., \& Phillips, S. F. (2000). American Gastroenterological Association medical position statement: guidelines on constipation. Gastroenterology, 119(6), 1761-1766. https://doi.org/10.1053/gast.2000.20390

Mansouri, A., Gattolliat, C. H., \& Asselah, T. (2018). Mitochondrial dysfunction and signaling in chronic liver diseases. Gastroenterology, 155(3), 629-647. https://doi.org/10.1053/j.gastro.2018.06.083

Mardalena, I. (2018). Nursing Care Patients with digestive system disorders. Yogyakarta: New Library press.

Marlett, J. A., \& Cheung, T. F. (1997). Database and quick methods of assessing typical dietary fiber intakes using data for 228 commonly consumed foods. Journal of the American Dietetic Association, 97(10), 11391151. https://doi.org/10.1016/S0002-8223(97)00275-7

Massacre \& Audina. (2018). The Effect of Avocado Juice (Persea Gratissima) On Changes in Constipation in the Elderly in Tresna Werdha Lotus Orphanage in Palembang City in 2016.

McCrea, G. L., Miaskowski, C., Stotts, N. A., Macera, L., Paul, S. M., \& Varma, M. G. (2009). Gender differences in self-reported constipation characteristics, symptoms, and bowel and dietary habits among patients attending a specialty clinic for constipation. Gender medicine, 6(1), 259-271. https://doi.org/10.1016/j.genm.2009.04.007

Mulyani, N. S. (2019). Asupan serat dan air sebagai faktor risiko konstipasi di kota Banda Aceh. Majalah Kesehatan Masyarakat Aceh (MaKMA), 2(1), 75-82.

Mustika, I. W., \& Harini, G. A. (2017). Increasing education of family support for decreasing depression level towards elderly. International Journal of Health Sciences, 1(3), 10-16. https://doi.org/10.21744/ijhs.v1i3.46

Mustika, I. W., \& Sudiantara, K. (2019). Effects of health promotion with family approaches on blood pressure and headache toward elderly. International Journal of Health Sciences,3(3), 8-16. https://doi.org/10.29332/ijhs.v3n3.344

Oktaviana, E. S., \& Setiarini, A. (2013). Hubungan asupan serat dan faktor-faktor lain dengan konstipasi fungsional pada mahasiswi reguler gizi Fakultas Kesehatan Masyarakat Universitas Indonesia tahun 2013= The relationship between fiber intake and other factors with functional constipation among regular class female student majoring nutrition Faculty of Public Health University of Indonesia in 2013.

Potter, P. A., \& Perry, A. G. (2005). Nursing fundamental teaching book: Concepts, processes, and practices, volume 1. Jakarta: EGC.

Gemini, S., Lolo, L. L., Sumiati, S., Ezdha, A. U. A., \& Susanti, N. Y. (2022). Correlation of fiber intakes with incidence of constipation in the elderly. International Journal of Social Sciences and Humanities, 6(1), 58-65. https://doi.org/10.53730/ijssh.v6n1.3528 
Purnomo, H., Apsari, A. E., \& Hadyanawati, A. A. (2019). Quality of life, health and environment in older adults: Nursing house stress aging assessment. International Journal of Social Sciences and Humanities, 3(1), 134142. https://doi.org/10.29332/ijssh.v3n1.272

Reicks, M., Jonnalagadda, S., Albertson, A. M., \& Joshi, N. (2014). Total dietary fiber intakes in the US population are related to whole grain consumption: results from the National Health and Nutrition Examination Survey 2009 to 2010. Nutrition research, 34(3), 226-234. https://doi.org/10.1016/j.nutres.2014.01.002

Riwidikdo, H. (2009). Health statistics. Yogyakarta: Nuha Medika.

Senate. (2018). Dietary Fiber in The Handling of Metabolic Syndrome. Yogyakarta: Gajah Mada University Press.

Stanhope, M., \& Lancaster, J. (2019). Public health nursing e-book: Population-centered health care in the community. Elsevier Health Sciences.

Sugiyanto, V. R. P., Rahfiludin, M. Z., \& Suyatno, S. (2017). Hubungan Asupan Serat, Lemak, Dan Posisi Buang Air Besar Dengan Kejadian Konstipasi Pada Lansi. Jurnal Kesehatan Masyarakat (Undip), 3(3), 257-265.

Suwananta, I. M. ., Nesa, N. N. M. ., Karyana, I. P. G. ., \& Putra, I. G. N. S. . (2020). Toilet training and less fiber consumption as risk factors of constipation in preschool children. International Journal of Health Sciences, 4(3), 83-92. https://doi.org/10.29332/ijhs.v4n3.474

Turan, N., Kaya, N., Kaya, H. O. A., Eskimez, Z., \& Yalcin, N. (2011). Constipation problems of nursing students with respect to certain variables. IUFN Nursing Journal, 19(3), 168-178.

Wild, T., Rahbarnia, A., Kellner, M., Sobotka, L., \& Eberlein, T. (2010). Basics in nutrition and wound healing. Nutrition, 26(9), 862-866. https://doi.org/10.1016/j.nut.2010.05.008

Winarto, W. (2004). Use vegetable plants to overcome various diseases. Tangerang: AgroMedia Pustaka. 


\section{Biography of Authors}

\begin{tabular}{|c|c|}
\hline & $\begin{array}{l}\text { Savitri Gemini } \\
\text { A lecturer in Nursing and Professional Education undergraduate study program at } \\
\text { the Mitra Bunda Persada Health Institute and the head of the study program. } \\
\text { completed his master's degree in Nursing in } 2015 \text { at Andalas University } \\
\text { Email: savitrigemini79@gmail.com }\end{array}$ \\
\hline & $\begin{array}{l}\text { Lestari Lorna Lolo } \\
\text { Lecturer at the bachelor of nursing Department at the Institute of Health and } \\
\text { Business Kurnia Jaya Persada. There have been several research results published } \\
\text { in national journal articles in Indonesia and international journals since } 2016 \text { until } \\
\text { now. In addition, she is also active as a researcher in the field of nursing. She is } \\
\text { also active as a book editor and also writes books. Currently, } 10 \text { books have been } \\
\text { published as a result of his editing and } 2 \text { books by his writings. } \\
\text { Email: thenextambition1@gmail.com }\end{array}$ \\
\hline & $\begin{array}{l}\text { Sumiati } \\
\text { Lecturer of Bachelor of Nursing at the Kurnia Jaya Persada Institute of Health and } \\
\text { Business located in Palopo City, South Sulawesi, Indonesia. So far, She has been } \\
\text { actively teaching, researching, and serving the community since becoming a } \\
\text { Lecturer, Her areas of interest are health science and health nursing. } \\
\text { Email: nssumiatigo@gmail.com }\end{array}$ \\
\hline & $\begin{array}{l}\text { Awaliyah Ulfah Ayudytha Ezdha } \\
\text { Lecturer of the Nursing Profession Program at STIKes Pekanbaru Medical Center } \\
\text { since 2016. Currently, her functional position is Lector (300). Actively running the } \\
\text { tri dharma of higher education until now. Specialization in Nursing Management } \\
\text { and Basic Nursing graduated from Nursing at the University of Riau and Master in } \\
\text { Hospital Administration at the University of Indonesia in 2016. Before becoming a } \\
\text { lecturer, she worked at Eka Hospital Pekanbaru. } \\
\text { Email: ditarhmn@gmail.com }\end{array}$ \\
\hline nosin & $\begin{array}{l}\text { Neny Yuli Susanti } \\
\text { She is a researcher at the Midwifery Study Program, Faculty of Health Sciences, } \\
\text { Ibrahimy University. In } 2008 \text { she graduated from D3 Midwifery at Darul Ulum } \\
\text { Islamic Boarding School Jombang, in 2010, graduated from D4 Midwifery at Stikes } \\
\text { Unggul Surabaya, and in } 2017 \text { graduated from S2 Midwifery at Padjadjaran } \\
\text { University Bandung. Currently, she is interested in Midwifery Care in Maternal } \\
\text { Maternity, has previously published several publications on technology-based } \\
\text { midwifery care such as the "Sahabat Umi" expert system, and is active in } \\
\text { community service activities, especially those based on midwifery care for } \\
\text { children, adolescents, pregnant women and mothers in labor. } \\
\text { Email: nenyyulisusanti@gmail.com }\end{array}$ \\
\hline
\end{tabular}

Gemini, S., Lolo, L. L., Sumiati, S., Ezdha, A. U. A., \& Susanti, N. Y. (2022). Correlation of fiber intakes with incidence of constipation in the elderly. International Journal of Social Sciences and Humanities, 6(1), 58-65. https://doi.org/10.53730/ijssh.v6n1.3528 